\title{
ETFS - PERFORMANCE, TRACKING ERRORS AND THEIR DETERMINANTS IN EUROPE AND THE USA
}

\author{
George Tsalikis *, Simeon Papadopoulos ** \\ * Corresponding author, Department of Accounting and Finance, University of Macedonia, Thessaloniki, Greece \\ Contact details: Department of Accounting and Finance, University of Macedonia, 156 Egnatia Street, \\ 54636 Thessaloniki, Greece \\ ** Department of Accounting and Finance, University of Macedonia, Thessaloniki, Greece
}

OPEN ACCESS
How to cite this paper: Tsalikis G.,
Papadopoulos, S. (2019). ETFS -
performance, tracking errors and their
determinants in Europe and the USA.
Risk Governance and Control: Financial
Markets \& Institutions, 9(4), 67-76.
http://doi.org/10.22495/rgcv9i4p6
Copyright @ 2019 The Authors
This work is licensed under a Creative
Commons Attribution 4.0 International
License (CC BY 4.0).
https://creativecommons.org/licenses/
by/4.0/
ISSN Online: $2077-4303$
ISSN Print: $2077-429 X$
Received: 03.10.2019
Accepted: 19.12 .2019
JEL Classification: G11, G14
DOI: 10.22495/rgcv9i4p6

\begin{abstract}
Exchange-traded funds (ETFs) have grown considerably since their first introduction two and a half decades ago, becoming one of the most popular passive investment vehicles among retail and professional investors. However, their tracking ability is often questioned. In this paper we estimate tracking errors from a sample of 15 American and European ETFs utilizing three different methods. We find that American ETFs seem to exhibit lower tracking errors than European ETFs in all measurements of tracking error. We also analyse and discuss the factors that influence tracking error. Fund size and expense ratios are found to be affecting the tracking ability of ETFs. The results of this study concerning the performance and tracking error determinants of ETFs are consistent with the evidence presented in the literature. To our knowledge, this is the first study to compare American and European ETFs in terms of their tracking ability and their tracking error determinants.
\end{abstract}

Keywords: ETFs, Tracking Error, Price Deviation, Assets under Management, Expense Ratios

Authors' individual contribution: Conceptualization - G.T.; Methodology - G.T.; Investigation - G.T.; Resources - G.T; Writing Original Draft - G.T. and S.P; Writing - Review \& Editing - S.P.; Supervision - S.P.; Funding Acquisition - G.T. and S.P.

\section{INTRODUCTION}

Exchange-traded funds are securities that track indexes, commodities or baskets of assets and trade like stocks in stock exchanges. They can be purchased and sold during the trading day like any other stock making it possible for private and institutional investors to acquire exposure to entire stock markets in different sectors of an economy or across countries and continents easily and at low costs. Exchange-traded funds are in essence index funds which are listed and traded on exchanges throughout the world like stocks as transactions can be made throughout the trading day and not just at the closing price of the day. Moreover, investors can sell short ETFs in margin accounts with the same margin rules that apply to common stocks. ETFs generally have a lower expense ratio than the equivalent passive mutual funds. Their structure is also different. The most important difference is the creation and redemption of ETF shares; contrary to mutual funds, ETFs do not sell or redeem their individual shares at net asset value (NAV).

Authorized participants will create or redeem ETF shares daily when arbitrage opportunities occur, ensuring that premiums or discounts which may arise are kept low. Should the market price of an ETF rise considerably above its net asset value (ETF trading at a premium), authorized participants will buy its underlying securities, create ETF shares in kind and then sell ETF shares in the market profiting from the difference. Similarly, if the market price of an ETF drops considerably below its net asset value (ETF trades at a discount), authorized participants may profit by buying ETF shares in the market, redeem them in kind and then sell the underlying securities. This mechanism helps ensure that differences between ETF market price and ETF net asset value are only short-lived. Curcio, Lipka, and Thornton (2004) have shown that the creationredemption process is indeed very effective in regulating the price of an ETF back to its NAV level eliminating any deviations. 
Over nearly a quarter of a century, exchange-traded funds have become one of the most popular passive investment vehicles among retail and professional investors because of their low transaction costs and high liquidity. By the end of 2016, the market share of ETFs exceeded $10 \%$ of the total market capitalization traded on US exchanges, representing more than 30\% of overall trading volume (Ben-David, Franzoni, \& Moussawi, 2017). There are many reasons for the rapid proliferation of ETFs in the previous years; the most important being diversification, tax efficiency, low management fees and transparency (Hill, Nadig, \& Hougan, 2015). Diversification helps investors avoid idiosyncratic risk. ${ }^{1}$ Modern portfolio theory asserts that a welldiversified portfolio with exposure in multiple asset classes with the extensive geographic focus can minimize idiosyncratic risk leaving only market risk. In the past decades, diversification could only be achieved by purchasing many different assets individually, a task not that easy for a private investor, or by investing in mutual funds that are actively managed by professionals. The introduction of exchange-traded funds in 1993 made diversification easier and more accessible for investors globally.

ETFs use various methods in order to track an index. The simplest way is to fully replicate its benchmark by purchasing all the securities that make up the index in exactly the same weight as in the index. This strategy might be best suited for indexes with a small number of components such as the Dow Jones Industrial Average. On the other hand, an ETF trying to fully replicate an index with thousands of securities like the Russell 3000 Index would face high transaction costs as its portfolio would have to be rebalanced every time the index changed its composition. Furthermore, not all markets are as liquid as the US market. It is not uncommon for ETFs to present tracking errors in their performance due to the transaction costs associated with matching the changes in their underlying index weights and compositions (Elton, Gruber, Commer, \& Li, 2002). Another way to follow an index is partial replication or sampling where only a representative sample of securities in an index is held in order to reduce transaction costs. This method produces lower transaction costs as the ETF needs to buy/sell fewer stocks but raises the possibility of tracking error between the ETF and its underlying index. Aside from full and partial replication, an ETF can gain its exposure to its benchmark with the use of derivatives like swaps. ETFs tracking indexes with this method are called synthetic ETFs. Synthetic replication is best suited for equity indexes with low liquidity, harder-toaccess markets, or commodities that are hard to store and preserve, for example, crude oil (Aggarwal \& Schofield, 2014). Synthetic ETFs hold an asset basket, ${ }^{2}$ called collateral, and enter into a swap with a counterparty ${ }^{3}$ that agrees to pay the ETF sponsor the performance of the ETF's benchmark index and in return the ETF sponsor pays the investment bank

\footnotetext{
${ }^{1}$ Idiosyncratic or unsystematic risk is the risk that is associated to the unique circumstances of a particular asset and not to market movements.

2 The asset basket may or may not be related with the benchmark index.

${ }^{3}$ Usually an investment bank.
}

the performance of the collateral (Ramaswamy, 2011).

As ETFs are growing in popularity amongst investors, the study of the performance of these funds demands attention. Hassine and Roncalli (2013) argue that for passive investments an investor's goal is to select the investment vehicle that tracks its benchmark index most accurately. In academic literature, ETFs are usually assessed by their tracking error, their liquidity and their yearly management fees. Tracking error is defined as the deviation between the performance of an ETF and its benchmark index (Shin \& Soydemir, 2010). The greater the tracking error the less closely the ETF follows the benchmark. An ETF perfectly replicating an index would have a tracking error of zero. In real world, however, this is not feasible as expenses, dividend payments to the stocks comprising an index and index rebalancing make perfect index replication not possible. The performance of passively managed funds is bound to vary from that of their target indices on account of market friction encountered by the funds while replicating the underlying index (Frino \& Gallagher, 2001).

This paper seeks to investigate the possible tracking error of American and European ETFs. This is very important to investors in determining whether and when to add ETFs in their portfolios. For this purpose, we use a sample of 15 American and European equity ETFs following broad indexes and study their performance. Another objective of this paper is to assess whether European ETFs, which haven't been much researched in academic literature, are as efficient as American ETFs in terms of tracking replication. Furthermore, we analyse and discuss the factors that influence tracking error. The size and expense ratio ${ }^{4}$ of the funds are the most cited determinants of tracking error in ETFs and both are examined in order to assess their importance.

This paper is organized as follows. Section 2 provides an extensive literature review of the studies on ETFs. Section 3 describes the data and descriptive statistics of the sample. Section 4 explains the research methodology employed and different definitions of tracking error. Section 5 discusses the empirical findings and the concluding remarks are offered in Section 6.

\section{LITERATURE REVIEW}

In the past decade, many scholars have shown considerable interest in exchange-traded funds. Most studies focus on their performance and tracking efficiency. Charteris (2013) studies the price efficiency of South African ETFs and finds that the vast majority of them trade at a premium to their NAVs, although usually, this divergence does not last for more than a couple of trading days. He concludes that the examined funds are reasonably efficiently priced. Ackert and Tian (2008) examine US-based American and international ETFs and find that the first are priced very close to their NAVs while the latter are not. They argue that the deviations exhibited in international funds are

${ }^{4}$ The expense ratio is the annual fee that exchange-traded funds charge their shareholders. 
correlated with momentum, size effects and lack of liquidity. Buetow and Henderson (2012) study a broad sample of ETFs traded on US stock exchanges and find that the daily returns of most of them track their benchmarks closely. However, some of them exhibit important tracking errors which tend to be larger for ETFs investing in indices composed of less liquid stocks. Kuok-Kun Chu (2011) studies ETFs traded in the Hong Kong stock exchange and finds that their tracking errors tend to be higher than those documented in US-traded funds. He also shows that the tracking errors are positively related to the expense ratios of the funds and negatively related to their assets under management (AUM). Defusco, Ivanov, \& Karels (2011) examine the three most liquid American ETFs and find that their price deviation is predictable and different from zero. They argue that the reason for the predictability of the pricing deviation is its stationarity and the reasons for the pricing deviations are the price discovery processes and dividend accumulation and distribution. Petajisto (2017) finds that the prices of US-traded and international ETFs tend to deviate frequently from their NAVs, especially for funds holding international or illiquid securities. He also shows that active trading strategies that exploit these inefficiencies can produce abnormal returns before transaction costs, proving the short-term mean reversion in ETF prices. Gutierrez, Martinez, \& Tse (2009) report that returns for Asian ETFs traded in the US are highly correlated with US stock markets which indicates that the trade prices of funds can be influenced by location. Johnson (2009) studies the tracking performance of US-listed ETFs on individual foreign countries and finds higher tracking errors when the opening hours of the foreign markets do not overlap with the stock exchanges on which the ETFs are traded. Similarly, Levy and Lieberman (2013) assess the pricing of international ETFs during overlapping trading hours vs non-overlapping trading hours. They find that during overlapping hours, the NAV returns have the biggest influence on ETF returns, whereas, when the foreign markets are closed, US market returns influence greatly ETF returns which shows that during non-overlapping trading hours, traders overreact to US market sentiments. Rompotis (2011) examines 50 index tracking ETFs over the period 2002 to 2007 and finds that the majority of the selected funds outperformed the S\&P500 and that their tracking error with respect to the benchmark index is strongly persistent in the short term. Sabbaghi (2011) studies 15 green ETFs within the period 2005 to 2009 and finds positive cumulative returns from their inception through to the end of 2008, and negative returns thereafter. Wong and Shum (2010) investigate the performance of 15 world ETFs that covered the bearish and bullish market from 1999 to 2007 and find that Sharpe ratio results show that ETFs constantly generated higher returns in the bullish market compared to the bearish market. Their tracking error is always positive both in bullish and bearish markets which means that investors are willing to pay a premium in ETF investments. Blitz and Huij (2012) examine the efficiency of emerging market ETFs and find that their tracking errors are higher than those of developed markets. Also, funds using synthetic replication techniques to track their benchmarks were more prone to high tracking errors than funds physically replicating their benchmarks. Finally, Huang and Lin (2011) discover that indirect portfolio investments in the form of country ETFs are more effective than foreign direct investments for the goal of diversification, and their relative efficiency in terms of performance measures.

Many researchers focus on the differences in performance between ETFs and index mutual funds and also whether the two investment vehicles are substitutes. Aber, Li, and Can (2009) study US-based ETFs and find that they are more likely to trade at a premium than at a discount. They also compare ETFs with conventional index mutual funds tracking the same index and find that in terms of tracking error; index mutual funds beat their corresponding ETF competitors by only 2-3 basis points. Gastineau (2004) assesses the performance of equity ETFs vs conventional index funds and finds that index funds outperform their benchmarks, unlike the examined ETFs. He suggests that ETFs' underperformance can be explained by the non-reinvestment of dividends. On the other hand, Ruan and Tongshu (2012) present evidence that ETFs are usually more actively traded, exhibit lower tracking errors, and have lower transaction costs and risk than closed-end funds. Also, Equity ETFs that track stock indices or economic sectors are more liquid than single stocks. Sharifzadeh and Hojat (2012) consider a sample of 230 paired ETFs and index mutual funds and find that there is statistically no significant difference in their performances. They argue that investors' choice between ETFs and index mutual funds depend more on product characteristics than on the performances at the funds' level. Miffre (2007) argues that ETFs can be a better alternative to global index open- or closed-end funds in terms of efficiency gains because of cost and tax efficiency and due to the fact that ETFs can be sold short (unlike equity funds). Hughen and Mathew (2009) compare closed-end funds and ETFs in terms of liquidity and arbitrage execution and find that they differ in liquidity and ease of arbitrage; the ETF returns are more closely related to their portfolio returns than are closed-end funds returns. Moreover, both fund types under-react to portfolio returns but overreact to domestic stock market returns. Barnhart and Rosenstein (2010) present evidence that closed-end funds' discounts widen significantly and trading volume decreases considerably when a similar ETF starts trading, suggesting that closed-end funds and ETFs are substitutes. Similarly, Agapova (2011) finds evidence in aggregate flows suggesting that index funds and ETFs are substitutes, but not perfect substitutes. She argues that their introduction to global markets was beneficial to investors as it increases competition in prices and adds novel service and product features. Finally, Blitz, Huij, and Swinkels (2012) study the performance of index mutual funds and exchange-traded funds listed in European stock exchanges that track major equity indexes internationally and find that European index funds and ETFs underperform their benchmark indexes by 50-150 basis points per year, which is considerably 
higher than the shortfalls reported for US-based passive funds in most studies. This underperformance is more than expected by the funds' expense ratio and can be attributed to dividend taxation. Once dividend taxes are taken into consideration, most of the passive funds' shortfalls are explained.

Other ETF studies were focused on tracking error determinants, ETF volatility, and the effect ETF trading has on the underlying stocks. Tse and Martinez (2007) compare the volatility of daytime returns to the volatility of overnight returns of 24 international iShares ETFs and find that the overnight variances are larger than the daytime variances for the iShares that track Asian and European markets, whereas the opposite is true for iShares that track North and South American markets. They believe that the volatility difference between US daytime and US overnight returns is due to the release of information in the local markets. Shin and Soydemir (2010) study 26 ETFs and find that tracking errors display persistence and are different from zero. Moreover, they show that the change in the exchange rate is a significant source of tracking errors. Qadan and Yagil (2012) investigate the tracking ability of US ETFs and find that tracking error is correlated with the daily volatility of the ETF; on the other hand, trading volume has a limited effect on reducing tracking errors. Marshall, Nguyen, and Visaltanachoti (2013) find that ETFs move ahead of the underlying stock portfolio, particularly when the liquidity of the underlying stocks is low. Price deviations from fair values are usually corrected within 2 minutes. Krause, Ehsani, and Lien (2014) show that the arbitrage activity between ETFs and their underlying stocks generates increases in intraday and daily stock volatility due to the transmission of liquidity shock from ETFs to the underlying stocks. Israeli, Lee, and Sridharan (2017) find that stocks owned by ETFs have higher trading costs, increased comovement with the index, and their stock prices reflect less firm-specific information. Sullivan and Xiong (2012) show that the rise in popularity of index mutual funds and ETFs have resulted in higher cross-sectional trading commonality and higher return correlations among stocks. Clifford, Fulkerson, and Jordan (2014) examine the drivers of equity ETF flows and discover that higher volume, smaller spreads, and higher price to net asset value ratios increase ETF flows. Chelley-Steeley and Park (2010) investigate the adverse selection component of ETFs and find that the ETFs have smaller adverse selection components than the stocks in their portfolio. They argue that this factor has greatly contributed to their popularity amongst investors. Broman (2016) reports that the size and direction of mispricing between US equity ETFs and their underlying securities comove across ETFs; he relates that with the high appeal of ETFs to short-term noise traders with correlated demand across investment styles. Lastly, Da and Shive (2018) find increased comovement in returns in the stocks comprising an index. They show that when investors trade on news related to the index, they trade the ETF more actively and thus the basket trading of the underlying stocks tied to the ETF through arbitrage exhibits higher return comovement with the index and a lower degree of idiosyncratic volatility.

\section{DATA AND DESCRIPTIVE STATISTICS}

The net asset values (NAVs) of ETFs, expense ratios, assets under management (AUM), benchmark indexes and inception dates were obtained from each fund's website from 01/01/2010 to $31 / 12 / 2018$ and information about each fund from their brochures. The daily benchmark index prices were obtained from Yahoo Finance.

The first ETF, Standard \& Poor's 500 Depositary Receipts (SPDRs), was introduced on the American Stock Exchange in 1993 tracking the S\&P 500. To that day it's the ETF with the largest assets under management, approximately $\$ 260$ billion. The first European ETFs were introduced later: the LDRs DJ STOXX 50 and the LDRs DJ Euro STOXX 50 were listed on the Deutsche Boerse, developed by Merrill Lynch International (Hill et al., 2015). Since then, ETFs have grown considerably and are used daily by private and retail investors worldwide, with their market experiencing significant growth. According to research company ETFGI, global ETFs' assets under management rose from USD 580 billion in 2006 to USD 4,820 billion in 2018 and their number rose from 727 ETFs to 7,620 ETFs in the same period. In 2006, the US-listed ETFs were 350 with USD 416 billion AUM, these numbers increased in 2017 to 1,834 ETFs and USD 3,331 billion AUM. The European ETF market also proliferated in the same period with 276 products listed and AUM of USD 94 billion in 2006 and 1,610 products listed and AUM of USD 762 billion in 2017. Both the number of ETFs and their AUM in US and European markets increased significantly, however, European ETFs stand for only a small fraction of the global market. One possible explanation may be the more recent inception of European funds, which means fewer years of trading. Moreover, according to Thomadakis (2018), the reason might be the fact that European ETFs have multiple listings over many exchanges and low engagement of retail investors compared to the US market.

Our sample consists of 15 ETFs, 5 American and 10 European following broad indexes. In Table 1, we present descriptive statistics for all funds included in the study with their ticker symbol, assets under management, yearly expense ratio, inception date, benchmark index, daily mean return and daily standard deviation. 
Table 1. ETF characteristics and descriptive statistics

\begin{tabular}{|c|c|c|c|c|c|c|c|}
\hline Name & Ticker & $\begin{array}{l}\text { Assets under } \\
\text { management }\end{array}$ & $\begin{array}{l}\text { Expense } \\
\text { ratio }\end{array}$ & $\begin{array}{l}\text { Inception } \\
\quad \text { date }\end{array}$ & $\begin{array}{l}\text { Underlying } \\
\text { index }\end{array}$ & $\begin{array}{c}\text { Mean } \\
\text { return (\%) }\end{array}$ & $\begin{array}{c}\text { Standard } \\
\text { deviation } \\
(\%)\end{array}$ \\
\hline SPDR S\&P 500 ETF & SPY & $\$ 242.27$ billion & $0.09 \%$ & $22 / 1 / 1993$ & S\&P 500 & 0.04013 & 0.94637 \\
\hline $\begin{array}{l}\text { iShares Core S\&P } 500 \\
\text { ETF }\end{array}$ & IVV & $\$ 151.44$ billion & $0.04 \%$ & $15 / 5 / 2000$ & S\&P 500 & 0.04027 & 0.94763 \\
\hline Invesco QQQ Trust & QQQ & $\$ 61.48$ billion & $0.20 \%$ & $10 / 3 / 1999$ & NASDAQ-100 & 0.05971 & 1.09585 \\
\hline $\begin{array}{l}\text { SPDR Dow Jones } \\
\text { Industrial Average ETF } \\
\text { Trust }\end{array}$ & DIA & $\$ 19.04$ billion & $0.17 \%$ & $14 / 1 / 1998$ & Dow Jones & 0.03965 & 0.89703 \\
\hline $\begin{array}{l}\text { iShares Russell } 2000 \\
\text { ETF }\end{array}$ & IWM & \$39.08 billion & $0.19 \%$ & $22 / 5 / 2000$ & Russell 2000 & 0.04140 & 1.25414 \\
\hline iShares Core FTSE 100 & ISF & $£ 5.59$ billion & $0.07 \%$ & $27 / 4 / 2000$ & FTSE 100 & 0.02169 & 0.95643 \\
\hline $\begin{array}{l}\text { Lyxor FTSE } 100 \text { UCITS } \\
\text { ETF }\end{array}$ & L100:LN & $£ 355.5$ million & $0.15 \%$ & $02 / 04 / 2007$ & FTSE 100 & 0.02730 & 0.95007 \\
\hline $\begin{array}{l}\text { iShares Core DAX } \\
\text { UCITS ETF DE }\end{array}$ & DAXEX & $€ 6,79$ billion & $0.16 \%$ & $27 / 12 / 2000$ & DAX & 0.03039 & 1.21779 \\
\hline $\begin{array}{l}\text { Lyxor DAX (DR) UCITS } \\
\text { ETF (Acc) }\end{array}$ & LYXDAX & $€ 839.9$ million & $0.15 \%$ & 01/06/2006 & DAX & 0.03118 & 1.22167 \\
\hline $\begin{array}{l}\text { Lyxor CAC } 40 \text { (DR) } \\
\text { UCITS ETF }\end{array}$ & CAC & $€ 4.07$ billion & $0.25 \%$ & $22 / 1 / 2001$ & CAC 40 & 0.01961 & 1.26085 \\
\hline $\begin{array}{l}\text { iShares FTSE MIB UCITS } \\
\text { ETF EUR }\end{array}$ & IMIB & $€ 145.1$ million & $0.35 \%$ & $06 / 7 / 2007$ & FTSE MIB & 0.00407 & 1.58799 \\
\hline LYXOR ETF FTSE MIB & ETFMIB & $€ 447.1$ million & $0.35 \%$ & $03 / 11 / 2003$ & FTSE MIB & 0.00752 & 1.57649 \\
\hline $\begin{array}{l}\text { LyXor EURO STOXX } 50 \\
\text { (DR) UCITS ETF (Dist) }\end{array}$ & MSE & $€ 5.79$ billion & $0.20 \%$ & $19 / 02 / 2001$ & EURO STOXX 50 & 0.02411 & 1.22115 \\
\hline $\begin{array}{l}\text { iShares Core EURO } \\
\text { STOXX } 50 \text { UCITS ETF } \\
\text { EUR (Dist) }\end{array}$ & EUN2 & $€ 4.12$ billion & $0.10 \%$ & $03 / 4 / 2000$ & EURO STOXX 50 & 0.02257 & 1.23853 \\
\hline iShares MSCI Spain ETF & EWP & $€ 887$ million & $0.47 \%$ & 12/3/1996 & $\begin{array}{l}\text { MSCI Spain } \\
\text { 25/50 Index }\end{array}$ & -0.00252 & 1.67083 \\
\hline
\end{tabular}

Notes: Expense ratios and assets under management are presented as of December 31, 2018. The mean return is the sample average of the simple daily returns from January 1, 2010, to December 31, 2018. Standard deviation is the sample standard deviation of the simple daily returns for each fund at the same time horizon.

Expense ratios range from $0.04 \%$ to $0.47 \%$. The average yearly expense ratio for the examined funds is $0.20 \%$. For the American funds the average yearly expense ratio is $0.14 \%$ whereas for the European funds $0.23 \%$. Moreover, American funds are vastly larger in size with an average amount of assets under management of USD 102.46 billion compared to USD 3.42 billion $^{5}$ for European funds.

\section{METHODOLOGY}

An ETF's tracking error is a critical measurement in order to determine an ETF's performance. Investors purchasing ETFs want to know how close they really follow an index in real market conditions. Tracking error is the difference between the return of an ETF and that of its benchmark. The higher the tracking error the less closely the ETF follows the benchmark Pope and Yadav (1994) propose three different definitions of tracking error.

The first way to measure the tracking error of a fund is by calculating the standard deviation of the return differences between the ETF and its benchmark index, which is calculated as follows:

$$
T E_{1}=\sqrt{\frac{1}{n-1} \sum_{t=1}^{n}\left(e_{i, t}-\overline{e_{l}}\right)^{2}}
$$

where $e_{i, t}=R_{E T F}-R_{I N D E X}$ and $n$ is the number of periods. The only shortback of this definition of tracking error is that if an ETF always underperforms the

\footnotetext{
${ }^{5}$ To convert AUM prices for European funds in USD, we used the currency
} exchange rates of December 31, 2018. benchmark by a constant amount, the tracking error measured by the standard deviation will be zero. Another way to measure the tracking error of a fund is the absolute difference in returns between the ETF and the index. This definition measures the extent to which the returns on an ETF differ from the returns of its underlying index over the sample period, and considers any absolute deviation in returns as tracking error. This definition of tracking error is calculated as follows:

$$
T E_{2}=\frac{\sum_{t=1}^{n}\left|e_{i, t}\right|}{n}
$$

where $e_{i, t}=R_{E T F}-R_{\text {INDEX }}$ and $n$ is the number of periods. The reason we do not use the simple difference between the return on ETFs and their benchmarks

$$
\left(\frac{\sum_{t=1}^{n} e_{i, t}}{n}\right)
$$

is that this approach can underestimate tracking errors because the differences tend to cancel each other out in the long run. A third way to measure the tracking error is to use standard errors from the regression analysis using daily returns on each ETF and its benchmark index. The model is:

$$
R_{E T F, t}=\alpha+\beta \cdot R_{\text {index }, t}+e_{t}
$$

Although this method should present similar results to $T E$, Pope and Yadav (1994) show that if $\beta$ is not exactly equal to one, then the regression residuals will be different from $T E$.

Initially, we calculate daily returns for all ETFs in the sample and their respective benchmark indices. Following most of ETF academic literature, 
we use NAV returns and not market price returns for the estimation of tracking errors to its benchmark. According to Osterhoff and Kaserer (2016) high-frequency trading and differences across various foreign exchanges' closing times for ETF and index trading, make it impossible to perfectly match daily ETF closing prices with the corresponding index prices. Furthermore, we use NAV returns and not market prices so as to be certain that potential price inefficiencies due to premiums and discounts in the market prices do not impede our results. The management of the funds is responsible for achieving the daily target return for the fund but has no control over potential market price inefficiencies. For investors buying ETFs, premiums and discounts tend to appear, but usually average deviations are small, as they tend to offset one another.

After calculating $T E_{1}, T E_{2}$ and $T E_{3}$ for all the examined funds we regress them on important characteristics of ETFs to find out if the tracking errors are correlated with these characteristics. Grinblatt and Titman (1989) have shown that fund size is a very important aspect as larger funds may have a lower transaction cost due to economies of scale, which results in better performance. Frino and Gallagher (2001) find that tracking errors are positively related to the funds' yearly expense ratios, which shows that lower expense ratios result in lower tracking errors and thus more close tracking of the benchmark index. Kuok-Kun Chu (2011) finds the magnitude of tracking errors to be negatively related to the size and positively related to the expense ratio of the ETFs which again shows that large ETFs should have lower trading costs and therefore lower tracking errors due to economies of scale; also, the funds with higher expense ratio will produce higher tracking errors. An increase in the size of a fund is likely to increase the performance of it with expenses now being shared by a larger fund base (Singh \& Kaur, 2016).

The independent variables in our study are the natural logarithm of the size of each ETF and its expense ratio. Therefore, the regression equation for the factors postulated to affect tracking errors can be expressed as:

$$
T E_{i, t}=\alpha+\beta \cdot S I Z E_{i, t}+\gamma \cdot E X P_{i, t}+e_{i, t}
$$

where $e_{i, t}$ is the error term and $T E_{i, t}$ is the tracking error measured by the three different definitions in period $t$ for fund $i$.

\section{EMPIRICAL RESULTS}

The tracking errors of each ETF examined are reported in Table 2. Based on the first definition of tracking error $\left(T E_{1}\right)$, the daily tracking error ranges from $\quad 0.050937 \%$ for SPDR Dow Jones Industrial Average ETF Trust to $0.307631 \%$ for iShares FTSE MIB UCITS ETF EUR with a sample average of $0.139982 \%$. The tracking error based on the second definition of tracking error $\left(T E_{2}\right)$, ranges from 0.016152\% for SPDR S\&P 500 ETF to $0.063038 \%$ for iShares FTSE MIB UCITS ETF EUR with a sample average of $0.033011 \%$. Lastly, the tracking error based on the third definition of tracking error $\left(T E_{3}\right)$, ranges from 0.000509 SPDR Dow Jones Industrial Average ETF Trust to 0.003071 for iShares FTSE MIB UCITS ETF EUR with a sample average of 0.001563 . In the regression analysis, all beta coefficients were statistically significant at the $1 \%$ level and very close to 1 , ranging from 0.974378 to 1.000558 . Most alpha coefficients were not statistically significant with a few exceptions where $\alpha$ was very close to zero. The $R^{2}$ values range from $96.26 \%$ to $99.83 \%$ indicating a strong linear fit. It is definitely not a coincidence that the ETF with the smallest size ( $€ 145.1$ million) exhibits one of the highest tracking errors in all 3 definitions whereas the largest ETFs in the world exhibit the lowest.

In Table 2 we observe that some simple return differences for ETFs are positive. Although they do not affect the three above mentioned definitions of tracking error we believe they are worth mentioning. In theory, it is desirable for an investor purchasing an ETF to outperform its benchmark for a given period. However, contrary to actively managed mutual funds, ETFs have the objective to track and not outperform their underlying index. Any deviation from its benchmark, positive or negative, is a breakdown of its objective. Investors not only buy ETFs but also short them. An investor that shorts ETFs will be hurt, not helped, by a possible outperformance and will righteously criticize the ETF managers for diverging of its stated objective. ETF managers have stated their intention to offer stable tracking rather than outperforming so that their funds can be just as useful for short sellers as buyers (Johnson, Bioy, Kellett, \& Davidson, 2013).

The average tracking errors of American and European ETFs are presented in Table 3. American ETFs seem to exhibit lower tracking errors than their European counterparts. The average $T E$ is $0.059665 \%$ for American ETFs and $0.180140 \%$ for European ETFs. The average $T E$ is $0.018889 \%$ for American ETFs and $0.040072 \%$ for European ETFs. Lastly, the average $T E_{3}$ is 0.000596 for American ETFs and 0.002047 for European ETFs. A possible explanation for this is that the average size of American funds is 29.9 times larger than the average size of European funds suggesting that there might be economies of scales that could lead to lower tracking errors for larger ETFs. 
Table 2. Tracking errors of the examined ETFs

\begin{tabular}{|c|c|c|c|c|c|c|c|c|}
\hline \multirow{2}{*}{ Name } & \multicolumn{2}{|c|}{$\begin{array}{l}\text { Return differences } \\
\frac{\sum_{t=1}^{n} e_{i, t}}{n}\end{array}$} & \multicolumn{2}{|c|}{$\begin{array}{c}\text { Absolute differences in } \\
\text { return } \\
\frac{\sum_{t=1}^{n}\left|e_{i, t}\right|}{n}\end{array}$} & \multicolumn{4}{|c|}{$\begin{array}{c}\text { Regression analysis } \\
R_{E T F, t}=\alpha+\beta \cdot R_{\text {index }, t}+e_{t}\end{array}$} \\
\hline & Mean (\%) & $\begin{array}{c}\text { Standard } \\
\text { deviation } \\
\left(T E_{1}\right)(\%)\end{array}$ & $\begin{array}{c}\operatorname{Mean}\left(T E_{2}\right) \\
(\%)\end{array}$ & $\begin{array}{l}\text { Standard } \\
\text { deviation } \\
\quad(\%)\end{array}$ & $\alpha$ & $\beta$ & $R^{2}$ & $\begin{array}{l}\text { Standard } \\
\text { error of } \\
\text { regression } \\
\left(T E_{3}\right)\end{array}$ \\
\hline $\begin{array}{l}\text { SPDR S\&P } 500 \\
\text { ETF }\end{array}$ & -0.000123 & 0.064925 & 0.016391 & 0.062821 & -0.0000001 & $0.998943^{* \ldots * *}$ & 0.995293 & 0.000649 \\
\hline $\begin{array}{l}\text { iShares Core S\&P } \\
500 \text { ETF }\end{array}$ & 0.000010 & 0.064203 & 0.016152 & 0.062137 & -0.0000002 & $1.000322 * * *$ & 0.995408 & 0.000642 \\
\hline $\begin{array}{l}\text { Invesco QQQ } \\
\text { Trust }\end{array}$ & -0.000419 & 0.067102 & 0.024453 & 0.050259 & -0.0000022 & 0.996691 *** & 0.996260 & 0.000670 \\
\hline $\begin{array}{l}\text { SPDR Dow Jones } \\
\text { Industrial } \\
\text { Average ETF } \\
\text { Trust }\end{array}$ & 0.000059 & 0.050937 & 0.019567 & 0.047027 & -0.0000010 & 0.998922 *光* & 0.996775 & 0.000509 \\
\hline $\begin{array}{l}\text { iShares Russell } \\
2000 \text { ETF }\end{array}$ & -0.005529 & 0.051157 & 0.017882 & 0.050848 & $-0.000055^{* * * *}$ & $0.999517^{* * * *}$ & 0.998336 & 0.000512 \\
\hline $\begin{array}{l}\text { iShares Core FTSE } \\
100\end{array}$ & -0.000012 & 0,130168 & 0.030057 & 0,126655 & -0.0000119 & $0.997972 * \cdots$ & 0.981473 & 0.001302 \\
\hline $\begin{array}{l}\text { Lyxor FTSE } 100 \\
\text { UCITS ETF }\end{array}$ & 0.001486 & 0.093276 & 0.020588 & 0.061652 & $0.000149 \cdots$ & 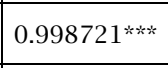 & 0.995564 & 0.001633 \\
\hline $\begin{array}{l}\text { iShares Core DAX } \\
\text { UCITS ETF DE }\end{array}$ & -0.002789 & 0.080532 & 0.037126 & 0.080265 & -0.0000263 & $0.995290 * * *$ & 0.995647 & 0.000803 \\
\hline $\begin{array}{l}\text { LyXor DAX (DR) } \\
\text { UCITS ETF - Acc }\end{array}$ & -0.001329 & 0.092069 & 0.047074 & 0.071733 & -0.0000130 & $0.999037 * * *$ & 0.996519 & 0.002721 \\
\hline $\begin{array}{l}\text { Lyxor CAC } 40 \\
\text { (DR) UCITS ETF }\end{array}$ & -0.001169 & 0.220641 & 0.035064 & 0.217839 & -0.0000110 & $0.995946^{* \ldots * *}$ & 0.969679 & 0.002206 \\
\hline $\begin{array}{l}\text { iShares FTSE MIB } \\
\text { UCITS ETF EUR }\end{array}$ & 0.000925 & 0.307631 & 0.063038 & 0.301101 & 0.0000096 & $0.987865 *$ & 0.962600 & 0.003071 \\
\hline $\begin{array}{l}\text { LYXOR ETF FTSE } \\
\text { MIB }\end{array}$ & -0.002665 & 0.209226 & 0.033682 & 0.206513 & -0.0000265 & $0.994641^{* \ldots * *}$ & 0.982510 & 0.002091 \\
\hline $\begin{array}{l}\text { LyXor EURO } \\
\text { STOXX } 50 \text { (DR) } \\
\text { UCITS ETF - Dist } \\
\end{array}$ & -0.002489 & 0.203408 & 0.029803 & 0.201226 & -0.0000250 & 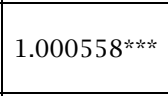 & 0.973393 & 0.002035 \\
\hline $\begin{array}{l}\text { iShares Core } \\
\text { EURO STOXX } 50 \\
\text { UCITS ETF EUR } \\
\text { (Dist) }\end{array}$ & 0.000829 & 0.216319 & 0.046208 & 0.211325 & 0.0000105 & $0.989731^{* \ldots *}$ & 0.969583 & 0.002160 \\
\hline $\begin{array}{l}\text { iShares MSCI } \\
\text { Spain ETF }\end{array}$ & -0.017580 & 0.248134 & 0,058080 & 0.241878 & $-0.000174 * *$ & $0.974378^{* * * *}$ & 0.979128 & 0.002443 \\
\hline
\end{tabular}

Notes: * statistically significant at the $10 \%$ level; ${ }^{* * *}$ statistically significant at the $5 \%$ level; ${ }^{* * * *}$ statistically significant at the $1 \%$ level.

Table 4 presents the results of regression analysis testing the significance of the determinants of tracking errors for the examined funds. The determinants of $T E_{3}, T E_{2}$ and $T E_{3}$ are size and expense ratio of the funds. Regardless of the measurement of tracking error the coefficient for size is negative and the coefficient for expenses is positive meaning that the size of a fund contributes to less tracking error whereas the higher the expenses of a fund the higher the tracking error. Not all examined variables are statistically significant though. When using $T E_{1}$ as an independent variable, size and expense ratio are statistically significant at $10 \%$ level. When using $T E_{2}$ as an independent variable, size is statistically significant at $5 \%$ level whereas the expense ratio is not statistically significant. Lastly, when using $T E_{3}$ as an independent variable, size is statistically significant at $1 \%$ level whereas the expense ratio is again not statistically significant. These results are consistent with Buetow and Henderson (2012) who found that fund size is negatively associated with the magnitude of tracking error, possibly suggesting scale is important for efficient fund management and Kuok-Kun Chu (2011) who found that tracking errors are negatively related to the size but positively related to the expense ratio of the ETFs. Furthermore, Singh and Kaur (2016) found the coefficient of AUM to be significantly negative, thus concluding that the asset size of an ETF impacts its performance positively. Regarding expense ratios, Rompotis (2011), Elton et al. (2002), Blitz et al. (2012) and Rowley and Kwon (2015) have also found that ETFs charging higher fees to their investors are likely to exhibit higher tracking errors and therefore underperform their target indexes. 
Table 3. Average tracking errors for American and European ETFs

\begin{tabular}{|c|c|c|c|c|c|c|c|c|}
\hline & \multicolumn{2}{|c|}{$\begin{array}{l}\text { Return differences } \\
\frac{\sum_{t=1}^{n} e_{i, t}}{n}\end{array}$} & \multicolumn{2}{|c|}{$\begin{array}{c}\text { Absolute differences in } \\
\text { return } \\
\frac{\sum_{t=1}^{n}\left|e_{i, t}\right|}{n}\end{array}$} & \multicolumn{4}{|c|}{$\begin{array}{c}\text { Regression analysis } \\
R_{E T F, t}=\alpha+\beta \cdot R_{\text {index }, t}+e_{t}\end{array}$} \\
\hline & Mean (\%) & $\begin{array}{c}\text { Standard } \\
\text { deviation } \\
\left(T E_{1}\right)(\%)\end{array}$ & $\begin{array}{c}\text { Mean } \\
\left(T E_{2}\right)(\%)\end{array}$ & $\begin{array}{l}\text { Standard } \\
\text { deviation } \\
\text { (\%) }\end{array}$ & $\alpha$ & $\beta$ & $R^{2}$ & $\begin{array}{l}\text { Standard } \\
\text { error of } \\
\text { regression } \\
\left(T E_{2}\right)\end{array}$ \\
\hline $\begin{array}{l}\text { Sample } \\
\text { average }\end{array}$ & -0.00205 & 0.139982 & 0.033011 & 0.132885 & -0.0000181 & 0.995236 & 0.985878 & 0.001563 \\
\hline $\begin{array}{l}\text { American } \\
\text { Funds' average }\end{array}$ & -0.00120 & 0.059665 & 0.018889 & 0.054618 & -0.0000117 & 0.998879 & 0.996414 & 0.000596 \\
\hline $\begin{array}{l}\text { European } \\
\text { Funds' average }\end{array}$ & -0.00248 & 0.180140 & 0.040072 & 0.172019 & -0.0000118 & 0.993414 & 0.980610 & 0.002047 \\
\hline
\end{tabular}

Table 4. Tracking error regressed on fund operating variables

\begin{tabular}{|c|c|c|c|}
\hline & \multicolumn{3}{|c|}{ Dependent variables } \\
\hline Variables & $\boldsymbol{T E}$ & $\boldsymbol{T E}_{2}$ & $\boldsymbol{T E}_{2}$ \\
\hline Intercept & $0.449549^{*}$ & $0.105511^{* *}$ & $0.008345^{* * *}$ \\
\hline Size & $-0.016427^{*}$ & $-0.003578^{* *}$ & $-0.000309^{* * *}$ \\
\hline Fee ratio & $0.299292^{*}$ & 0.039289 & 0.000697 \\
\hline
\end{tabular}

Notes: * statistically significant at the $10 \%$ level; ${ }^{* *}$ statistically significant at the $5 \%$ level; ${ }^{* * * *}$ statistically significant at the $1 \%$ level

\section{CONCLUSION}

ETFs have grown considerably since their first introduction in 1993 becoming one of the most popular passive investment vehicles among retail and professional investors because of their low transaction costs and high liquidity. This study finds that some ETFs exhibit noticeable tracking errors while trying to replicate the performance of their underlying indices. This is somehow expected as ETFs frequently suffer deviations in performance compared to their underlying indexes because of frictions occurring in the market. Investors should be concerned with tracking errors as these can result in a performance of the ETF that deviates importantly from the benchmark that the investor is seeking exposure to.

Following academic literature on fund performance, we estimate three different measurements of tracking errors which are the standard deviation of the return differences between the ETF and its benchmark index, the absolute difference in returns between the ETF and the index and the standard errors from the regression analysis using daily returns on each ETF and its benchmark index. After examining a sample that consists of 15 ETFs, 5 American and 10 European funds following broad indexes we find that American ETFs seem to exhibit lower tracking errors than European ETFs in all three different measurements of tracking error. A possible explanation for this might be that the average size of American funds is 29.9 times larger than the average size of European funds suggesting that there may be economies of scales that could lead to lower tracking errors for the funds. To our knowledge, this is the first study to compare American and European ETFs in terms of their tracking ability and their tracking error determinants.

This paper further asserts that the tracking abilities of ETFs are highly affected by the size of the funds as measured by their assets under management. AUM is reported to have a positive and statistically significant impact on the tracking ability of ETFs regardless of the measurement of tracking error and therefore investors, while considering investment in ETFs, should definitely examine them. These results are consistent with Buetow and Henderson (2012), Kuok-Kun Chu (2011) and Singh and Kaur (2016) who found that the asset size of an ETF impacts its performance positively. Furthermore, the coefficient for expenses is positive regardless of the measurement of tracking error, meaning that the higher the expenses of a fund the higher the tracking error. However, it is statistically significant only for $T E$. Rompotis (2011), Elton et al. (2002), Blitz et al. (2012) and Rowley and Kwon (2015) have also found that ETFs that charge higher expense ratios are likely to exhibit higher tracking errors and thus underperform their benchmark indexes.

One limitation of the research is the fact that the study only covers the period 2010-2018; it would be interesting to include in future studies the 2008-2009 financial crisis and compare ETF performance and tracking errors between different time periods. Also, ETF performance since each fund's inception could be measured to include all years each ETF trades. Furthermore, another limitation of the study is the use of only US and European equity funds. It would be useful to examine in future research broader samples of ETFs from different geographic areas. It would also be desirable to investigate other types of ETFs such as fixed-income ETFs, commodity ETFs, currency ETFs and leveraged ETFs in order to provide more general information about the global ETF market. Future research may examine the impact of the introduction of ETFs on the quality of the market and the effect they may have on underlying securities. Another interesting topic is the examination for potential interactive effects of the components of pricing deviation, ETF premium/discount and ETF tracking error, on an intraday basis. The diversity of the literature is expected to grow with the constant innovations of the ETF industry. As new products become popular among the investment community, they will naturally attract more attention from future academics. 


\section{REFERENCES}

1. Aber, J. W., Li, D., \& Can, L. (2009). Price volatility and tracking ability of ETFs. Journal of Asset Management, 10(4), 210-221. https://doi.org/10.1057/jam.2009.13

2. Ackert, L. F., \& Tian, Y. S. (2008). Arbitrage, liquidity, and the valuation of exchange traded funds. Financial Markets, Institutions \& Instruments, 17(5), 331-362. https://doi.org/10.1111/j.1468-0416.2008.00144.x

3. Agapova, A. (2011). Conventional mutual index funds versus exchange-traded funds. Journal of Financial Markets, 14(2), 323-343. https://doi.org/10.1016/j.finmar.2010.10.005

4. Aggarwal, R., \& Schofield, L. (2014). The growth of global ETFs and regulatory challenges. Advances in Financial Economics, 16, 77-102. https://doi.org/10.1108/S1569-3732(2013)0000016003

5. Barnhart, S. W., \& Rosenstein, S. (2010). Exchange-traded fund introductions and closed-end fund discounts and volume. The Financial Review, 45(4), 973-994. https://doi.org/10.1111/j.1540-6288.2010.00281.x

6. Ben-David, I., Franzoni, F., \& Moussawi, R. (2017). Exchange traded funds. Annual Review of Financial Economics, 9, 169-189. https://doi.org/10.1146/annurev-financial-110716-032538

7. Blitz, D., \& Huij, J. (2012). Evaluating the performance of global emerging markets equity exchange-traded funds. Emerging Markets Review, 13(2), 149-158. https://doi.org/10.1016/j.ememar.2012.01.004

8. Blitz, D., Huij, J., \& Swinkels, L. (2012). The performance of European index funds and exchange-traded funds. European Financial Management, 18(4), 649-662. https://doi.org/10.1111/j.1468-036X.2010.00550.x

9. Broman, M. S. (2016). Liquidity, style investing and excess comovement of exchange-traded fund returns. Journal of Financial Markets, 30, 27-53. https://doi.org/10.1016/j.finmar.2016.05.002

10. Buetow, G. W., \& Henderson, B. J. (2012). An empirical analysis of exchange-traded funds. The Journal of Portfolio Management, 38(4), 112-127. https://doi.org/10.3905/jpm.2012.38.4.112

11. Charteris, A. (2013). The price efficiency of South African exchange traded funds. Investment Analysts Journal, 42(78), 1-11. https://doi.org/10.1080/10293523.2013.11082558

12. Chelley-Steeley, P., \& Park, K. (2010). The adverse selection component of exchange traded funds. International Review of Financial Analysis, 19(1), 65-76. https://doi.org/10.1016/j.irfa.2009.09.003

13. Clifford, C. P., Fulkerson, J. A., \& Jordan, B. D. (2014). What drives ETF flows? The Financial Review, 49(3), 619642. https://doi.org/10.1111/fire.12049

14. Curcio, R. J., Lipka, J. M., \& Thornton, J. H. (2004). Cubes and the individual investor. Financial Services Review, 13, 123-138. Retrieved from http://citeseerx.ist.psu.edu/viewdoc/download?doi=10.1.1.392.4068\&rep= rep1\&type $=$ pdf

15. Da, Z., \& Shive, S. (2018). Exchange traded funds and asset return correlations. European Financial Management, 24(1), 136-168. https://doi.org/10.1111/eufm.12137

16. Defusco, R. A., Ivanov, S. I., \& Karels, G. V. (2011). The exchange traded funds' pricing deviation: Analysis and forecasts. Journal of Economics and Finance, 35(2), 181-197. https://doi.org/10.1007/s12197-009-9090-6

17. Drenovak, M., Urošević, B., \& Jelic, R. (2014). European bond ETFs: Tracking errors and the sovereign debt crisis. European Financial Management, 20(5), 958-994. https://doi.org/10.1111/j.1468-036X.2012.00649.x

18. Elton, E. J., Gruber, M. J., Commer, G., \& Li, K. (2002). Spiders: Where are the bugs. The Journal of Business, 75(3), 453-472. https://doi.org/10.1086/339891

19. Frino, A., \& Gallagher, D. R. (2001). Tracking S\&P 500 index funds. The Journal of Portfolio Management, 28(1), 44-55. https://doi.org/10.3905/jpm.2001.319822

20. Gastineau, G. L. (2004). The benchmark index ETF performance problem. The Journal of Portfolio Management, 30(2), 96-103. https://doi.org/10.3905/jpm.2004.319935

21. Grinblatt, M., \& Titman, S. (1989). Mutual fund performance: An analysis of quarterly portfolio holdings. The Journal of Business. 62(3), 393-416. https://doi.org/10.1086/296468

22. Gutierrez, J. A., Martinez, V., \& Tse, Y. (2009). Where does return and volatility come from? The case of Asian ETFs. International Review of Economics and Finance, 18(4), 671-679. https://doi.org/10.1016/j.iref.2009.02.012

23. Hassine, M., \& Roncalli, T. (2013). Measuring performance of exchange traded funds. The Journal of Index Investing, 4(3), 57-85. https://doi.org/10.3905/jii.2013.4.3.057

24. Hill, J. M., Nadig, D., \& Hougan, M. (2015). A comprehensive guide to exchange-traded funds (ETFs). Retrieved from https://www.cfainstitute.org/-/media/documents/book/rf-publication/2015/rf-v2015-n3-1-pdf.ashx

25. Huang, M.-Y., \& Lin, J.-B. (2011). Do ETFs provide effective international diversification? Research in International Business and Finance, 25(3), 335-344. https://doi.org/10.1016/j.ribaf.2011.03.003

26. Hughen, J. C., \& Mathew, P. G. (2009). The efficiency of international information flow: Evidence from the ETF and CEF prices. International Review of Financial Analysis. 18(1-2), 40-49. https://doi.org/10.1016/j.irfa.2008.12.001

27. Israeli, D., Lee, C. M. C., \& Sridharan, S. A. (2017). Is there a dark side to exchange traded funds? An information perspective. Review of Accounting Studies. 22(3), 1048-1083. https://doi.org/10.1007/s11142-017-9400-8

28. Johnson, B., Bioy, H., Kellett, A., \& Davidson, L. (2013). On the right track: Measuring tracking efficiency in ETFs. The Journal of Index Investing, 4(3), 35-41. https://doi.org/10.3905/jii.2013.4.3.035

29. Johnson, W. F. (2009). Tracking errors of exchange traded funds. Journal of Asset Management, 10(4), $253-262$. https://doi.org/10.1057/jam.2009.10

30. Krause, T., Ehsani, S., \& Lien, D. (2014). Exchange-traded funds, liquidity and volatility. Applied Financial Economics. 24(24), 1617-1630. https://doi.org/10.1080/09603107.2014.941530

31. Kuok-Kun Chu, P. (2011). Study on the tracking errors and their determinants: Evidence from Hong Kong exchange traded funds. Applied Financial Economic, 21(5), 309-315. https://doi.org/10.1080/09603107.2010.530215

32. Levy, A., \& Lieberman, O. (2013). Overreaction of country ETFs to US market returns: Intraday vs. daily horizons and the role of synchronized trading. Journal of Banking and Finance, 37(5), 1412-1421. https://doi.org/10.1016/j.jbankfin.2012.03.024

33. Marshall, B. R., Nguyen, N. H., \& Visaltanachoti, N. (2013). ETF arbitrage: Intraday evidence. Journal of Banking and Finance, 37(9), 3486-3498. https://doi.org/10.1016/j.jbankfin.2013.05.014

34. Miffre, J. (2007). Country-specific ETFs: An efficient approach to global asset allocation. Journal of Asset Management, 8(2), 112-122. https://doi.org/10.1057/palgrave.jam.2250065

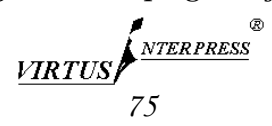


35. Osterhoff, F., \& Kaserer, C. (2016). Determinants of tracking error in German ETFs - the role of market liquidity. Managerial Finance, 42(5), 417-437. https://doi.org/10.1108/MF-04-2015-0105

36. Petajisto, A. (2017). Inefficiencies in the pricing of exchange-traded funds. Financial Analysts Journal, 73(1), 2454. https://doi.org/10.2469/faj.v73.n1.7

37. Pope, P. F., \& Yadav, P. K. (1994). Discovering errors in tracking error. The Journal of Portfolio Management, 20(2), 27-32. https://doi.org/10.3905/jpm.1994.409471

38. Qadan, M., \& Yagil, J. (2012). On the dynamics of tracking indices by exchange traded funds in the presence of high volatility. Managerial Finance, 38(9), 804-832. https://doi.org/10.1108/03074351211248162

39. Ramaswamy, S. (2011). Market structures and systemic risks of exchange-traded funds (Bank of International Settlements Working papers No. 343). Retrieved from https://www.bis.org/publ/work343.pdf

40. Rompotis, G. G. (2011). Predictable patterns in ETFs' return and tracking error. Studies in Economics and Finance, 28(1), 14-35. https://doi.org/10.1108/10867371111110534

41. Rowley, J. J., \& Kwon, D. T. (2015). The ins and outs of index tracking. The Journal of Portfolio Management, 41(3), 35-45. https://doi.org/10.3905/jpm.2015.41.3.035

42. Ruan, J., \& Tongshu, M. (2012). Ex-dividend day price behavior of exchange-traded funds. The Journal of Financial Research, 35(1), 29-53. https://doi.org/10.1111/j.1475-6803.2011.01308.x

43. Sabbaghi, O. (2011). The behavior of green exchange-traded funds. Managerial Finance, 37(5), 426-441. https://doi.org/10.1108/03074351111126915

44. Sharifzadeh, M., \& Hojat, S. (2012). An analytical performance comparison of exchange-traded funds with index funds: 2002-2010. Journal of Asset Management, 13(3), 196-209. https://doi.org/10.1057/jam.2012.3

45. Shin, S., \& Soydemir, G. (2010). Exchange-traded funds, persistence in tracking errors and information dissemination. Journal of Multinational Financial Management, 20(4-5), $214-234$. https://doi.org/10.1016/j.mulfin.2010.07.005

46. Singh, J., \& Kaur, P. (2016). Tracking efficiency of exchange traded funds (ETFs): Empirical evidence from Indian equity ETFs. Paradigm, 20(2), 176-190. https://doi.org/10.1177/0971890716670722

47. Sullivan, R. N., \& Xiong, J. X. (2012). How index trading increases market vulnerability. Financial Analysts Journal, 68(2), 70-84. https://doi.org/10.2469/faj.v68.n2.7

48. Thomadakis, A. (2018). The European ETF market: What can be done better? ECMI Commentary, 53. Retrieved from https://www.ceps.eu/ceps-publications/european-etf-market-what-can-be-done-better/

49. Tse, Y., \& Martinez, V. (2007). Price discovery and informational efficiency of international iShares funds. Global Finance Journal, 18(1), 1-15. https://doi.org/10.1016/j.gfj.2007.02.001

50. Wong, K. H., \& Shum, W. C. (2010). Exchange-traded funds in bullish and bearish markets. Applied Economics Letters, 17(16), 1615-1624. https://doi.org/10.1080/13504850903085035 